Awbery, Prof. L. F. Bates, Dr. R. C. Evans, Dr. C. E. Wynn-Williams.

The officers for 1947-48 of the four Groups of the Society are as follows: Colour Group: Chairman, Mr. J. G. Holmes; Hon. Secretary, Dr. W. D. Wright; Optical Group: Chairman, Prof. L. C. Martin; Hon. Secretary, Mr. E. W. H. Selwyn; Low-Temperature Group: Chairman, Sir Alfred Egerton; Hon. Secretary, Mr. G. G. Haselden; Acoustics Group: Chairman, Mr. H. L. Kirke; Hon. Secretaries, Mr. W. H. Allen and Mr. A. T. Pickles.

\section{University of Glasgow: Appointments}

THE following appointments in the University of Glasgow have been announced : Prof. G. W. Wishart, professor of physiological chemistry, is to become director of post-graduate medical education. Mr. J. R. Anderson has been appointed lecturer in pathology ; Dr. W. F. Anderson, lecturer in materia medica; Dr. J. C. D. Brand (of King's College, London), lecturer in chemistry; Dr. S. A. Hutchinson (formerly with the Distillers' Co., Ltd.), lecturer in botany; and Mr. A. C. Robb, Nuffield research assistant in physics.

\section{Congresses}

International Conference on the Emission from the Aurora and the Night Sky

AN international conference to discuss the emission from the aurora and the night sky is being arranged under the auspices of the Gassiot Committee of the Royal Society. This will be held in London during July $7-11$ at the rooms of the Royal Society at Burlington House.

\section{Conference on the Strength of Solids}

A DETAILED programme has now been prepared of the Conference on the Strength of Solids to be held at the H. H. Wills Physical Laboratory, University of Bristol, during July 7-10 (see Nature, Feb. 8, p. 193). The topics to be discussed include hardening of metals by internal oxidation (J. L. Meyering, Eindhoven), rate of approach to the ordered state in alloys (M. Weil, Grenoble), mechanical properties of metals at low temperatures (Prof. M. J. Druyvesteyn, Delft), creep in metals (Prof. E. N. da C. Andrade, Dr. E. Orowan and Dr. B. Chalmers), recovery and recrystallization (Prof. W. G. Burgers, Delft), hardness and crystal size (Sir Lawrence Bragg), thermo-electric methods of studying diffusion (C. Crussard, Paris), internal friction in metals (Prof. L. Guillet, Paris), elastic after-effects in iron (Prof. H. B. G. Casimir, Eindhoven) and sintered artefacts (J. H. McKee).

\section{Nuclear Physics in Biological and Medical Sciences}

THE University of California Medical School, in association with University Extension, University of California, has arranged a course in the application of nuclear physics to the biological and medical sciences. This course will be given at the Medical Center, San Francisco, during June 30-July 18. There will be lectures, laboratory demonstrations and seminars for round-table discussions. The course is open to those interested in the field of medical and biological research. The first week will be devoted to lectures, etc., on the general subject, the second week to the radioactive 'tracers' in biology and medicine and the third to therapeutic and diagnostic aspects of 'tracer' elements. Detailed information can be obtained from Dr. Stacy R. Mettier, head of the Postgraduate Instruction Medical Extension, University of California Medical Center, San Francisco 22, California.

\section{Industrial Utilization of Agricultural Products and of Seaweed}

A Colloquium on the Industrial Utilization of Agricultural Products and of Seaweed, arranged by the Irish Chemical Association and the Dublin Section of the Royal Institute of Chemistry, will be held in the Department of Chemistry, University College, Dublin, on July 2 and 3 . The meetings will be opened by the Minister for Industry and Commerce of Eire, and the first session will be a general survey opened by Prof. J. L. Simonsen, director of the Colonial Products Research Council, London, who will speak on "Agricultural Products and the Chemical Industry". The second session, on seaweed, will be opened by Prof. J. B. Speakman, professor of textile industries, University of Leeds, with a paper on "The Production, Properties and Uses of Seaweed Rayon". The third session will deal with carbohydrates, and will be opened by a paper by Prof. E. L. Hirst, Sir Samuel Hall professor of chemistry, University of Manchester, on "The Utilization of Carbohydrate Products". On July 3, there will be a Government reception at Phœnix Park, Dublin.

\section{Announcements}

Sir Robert Robinson, Waynflete professor of chemistry in the University of Oxford, and Prof. P. Karrer, professor of chemistry in the University of Zurich, have been elected Correspondants for the Section of Chemistry of the Paris Academy of Sciences. Sir Robert Robinson has also recently been elected a foreign member of the Royal Norwegian Academy of Sciences.

A conversazione of the Royal Society is being held at the Society's rooms on May 29 at 8.30 p.m.

Mr. J. Davidson PratT, director and secretary of the Association of British Chemical Manufacturers, has been awarded by the American Government the Medal of Freedom with silver palms for exceptionally meritorious work and co-operation with the United States while Controller of Chemical Defence Development at the Ministry of Supply during 1940-45.

THE Ministry of Supply announces the following appointments to the Minister's Advisory Council on Scientific Research and Technical Development: Prof. Wesley Austin, Goldsmith's professor of metallurgy in the University of Cambridge; Prof. W. E. Curtis, professor of physics at King's College, Newcastle; Lord Hankey; Prof. Willis Jackson, professor of electrical engineering at the Imperial College of Science and Technology, London; Prof. E. K. Rideal, Fullerian professor of chemistry at the Royal Institution; Mr. S. Robson, of the Imperial Smelting Corporation of Bristol.

Dr. E. C. Amoroso, reader in histology and embryology at the Royal Veterinary College, London, has been appointed to the chair of veterinary physiology in the College.

Erratum. In the communication "Phase-Contrast in the Photomicrography of Metals", in Nature, May 10, p. 639 , par. 6, for " $42-\mathrm{mm}$. oil immersion" read "2-mm. oil immersion". 